\title{
KEPRAKTISAN PANDUAN PRAKTIKUM IPA SEDERHANA SEKOLAH DASAR (SD) BERORIENTASIKAN LINGKUNGAN SEKITAR
}

\author{
N.W. S. Darmayanti ${ }^{1}$, I.K.Wisnu Budi Wijaya ${ }^{2)}$, N.P.A. H. Sanjayanti²) \\ 1)Program Studi Pendidikan Guru Sekolah Dasar, STKIP Suar Bangli \\ 2)Program Studi Pendidikan Guru Sekolah Dasar, IHDN Denpasar \\ ${ }^{3)}$ Program Studi Teknik Komputer, Politeknik Ganesha Guru \\ Coresponding author : N.W. S. Darmayanti \\ Email: wyndarmayanti@gmail.com
}

Diterima 08 Oktober 2020, Direvisi 02 November 2020, Disetujui 02 November 2020

\begin{abstract}
ABSTRAK
Penelitian ini bertujuan untuk mengetahui tingkat keterpakaian produk yang dikembangkan dalam hal ini panduan praktikum IPA sederhana SD berorientasikan lingkungan sekitar. Jenis penelitian ini merupakan penelitian deskriptif. Panduan praktikum menjadi subyek dalam penelitian dan kepraktisan dari panduan praktikum yang dirancang sebagai objek penelitian. Pada penelitian ini tingkat kepraktisan diukur dengan menggunakan angket yang diberikan kepada siswa untuk melihat tanggapan siswa dalam penggunaan panduan praktikum. Data dianalisis menggunakan skala likert untuk menganalisis tingkat kepraktisan produk. Skala likert adalah skala yang memiliki gradulasi penilaian, yaitu sangat baik (5), baik (4), kurang baik (3), tidak baik (2) dan sangat tidak baik (1). Data kepraktisan yang telah diisi melalui angket dan kemudian dijumlahkan. Total skor yang sudah diperoleh dikonversikan menjadi data kualitatif dengan skala lima. Hasil penelitian menunjukkan bahwa telah teruji kepraktisan dari praktikum IPA sederhana SD berorientasikan lingkungan sekitar. Di mana skor dengan kriteria sangat praktis berjumlah 3 orang dengan persentase $8 \%$, kriteria cukup praktis berjumlah 2 orang dengan persentase $6 \%$ dan kriteria praktis berjumlah 30 orang dengan persentase $86 \%$. Keseluruhan skor rata-rata kepraktisan panduan praktikum adalah 25 dan memilki kriteria praktis.
\end{abstract}

Kata kunci: kepraktisan; panduan praktikum; lingkungan sekitar

\begin{abstract}
This study aims to determine the usability level of the product developed in this case a simple natural science practical guide for elementary school oriented environment. This type of research is a descriptive study. The practicum guide is the subject of research and the practicality of the practicum guide which is designed as an object of research. In this study, the level of practicality was measured using a questionnaire given to students to see student responses after using the practicum guide. The data were analyzed using a Likert scale to analyze the practicality of the product. The Likert scale is a scale that has a gradation of ratings, namely very good (5), good (4), not good (3), not good (2) and very bad (1). Practicality data that has been filled in through a questionnaire and then added up. The total score that has been obtained is converted into qualitative data on a scale of five. The results showed that the practicality of a simple natural science practicum elementary school oriented environment has been tested. Where the score with very practical criteria amounted to 3 people with a percentage of $8 \%$, the criteria were quite practical amounting to 2 people with a percentage of $6 \%$ and the practical criteria were 30 people with a percentage of $86 \%$. The overall practicality average score of the practicum guide is 25 and has practical criteria.
\end{abstract}

Keywords: practicality; practical guide; environment

\section{PENDAHULUAN}

Sumber daya manusia (SDM) yang berkualitas dapat terwujud tidak terlepas dari faktor pendidikan yang semakin maju dan berkualitas pula. Salah satu usaha yang sudah dilakukan pemerintah dalam memajukan pendidikan di Indonesia salah satunya adalah perbaikan kurikulum yang diterapkan di sekolah-sekolah. Dari tahun ke tahun kurikulum sudah direvisi sehingga akhirnya pada saat ini diterapkan kurikulum 2013 yang sering disingkat K-13. Fadlillah (2014) menyatakan bahwa kurikulum 2013 menekankan pada peningkatan dan keseimbangan soft skills dan hard skills.Kurikulum ini mengarah pada penerapan dari hakikat sains itu sendiri. Berbagai sumber menyatakan bahwa sikap dan nilai terdapat dalam penerapan produk, proses dan penerapannya (teknologi). Belajar IPA 
memiliki dimensi proses, dimensi hasil (produk), dan dimensi pengembangan sikap ilmiah. Ketiga dimensi tersebut bersifat saling terkait. Ini berarti bahwa proses belajar mengajar IPA seharusnya mengandung ketiga dimensi IPA tersebut (Sulistyorini, 2007).

Depdiknas Tahun 2016, yang menyatakan bahwa pendidikan IPA diarahkan untuk inkuiri sehingga dapat membantu siswa dalam memperoleh pemahaman tentang alam sekitar. Proses pembelajaran secara inkuiri salah satunya dapat dilakukan melalui praktikum. Praktikum merupakan kegiatan laboratorium sebagai penunjang pembelajaran IPA. Pembelajaran IPA di Sekolah Dasar (SD) perlu melakukan pengamatan atau praktikum karena pelajaran IPA tidak semata-mata belajar hafalan materi atau teori saja (Susanto, 2013). Sesuai dengan pernyataan tersebut, kegiatan praktikum sangat perlu dilaksanakan dalam pembelajaran IPA SD.

Kegiatan Praktikum/eksperimen menurut Djamarah (2006) adalah suatu kegiatan di mana siswa sendiri membuktikan teori yang mereka pelajari melalui percobaan atau pengamatan secara langsung. Selain itu, kegiatan praktikum juga dapat diartikan proses pembelajaran dengan melibatkan siswa secara langsung untuk membuktikan sendiri teori melalui pengamatan atau praktikum dengan alat-alat yang ada pada laboatorium secara berkelompok ataupun perseorangan (Mulyasa, 2006). Sesuai dengan pendapat tersebut, praktikum adalah salah suatu bentuk kegiatan proses pembelajaran yang melibatkan siswa secara langsung untuk melakukan pengamatan/eksperimen baik itu di dalam laboratorium maupun di Lingkungan sekitar. Menurut Dahar (1986) bahwa kegiatan praktikum tersebut adalah salah satu kegiatan yang dapat mengembangkan keterampilan proses IPA siswa sehingga kegiatan praktik perlu ditekankan dalam pembelajaran IPA (Kunandar, 2007).

Hal ini didukung oleh hasil penelitian lepiyanto (2014) di mana Keterampilan proses sains siswa meningkat melalui kegiatan praktikum. Keterampilan Proses Sains (KPS) adalah keterampilan dalam pembelajaran IPA dengan menerapkan metode ilmiah dalam pembelajarannya sehingga siswa menjadi lebih mengerti dengan konsep-konsep yang telah dipelajari dan tetap melekat dibenaknya (Ratnasari et al., 2018). Selanjutnya menurut Rustaman (2005) keterampilan proses sains adalah kemampuan atau keterampilan siswa dalam menemukan konsep-konsep/teori-teori IPA melalui pengamatan atau eksperimen. Keterampilan proses sains adalah tujuan utama konsep sains. Keterampilan ini termasuk untuk penyelidikan ilmiah yang juga mendukung pembelajaran sains abad ke-21 Chiappetta \& Koballa (dalam Rani dkk, 2017).

Dari paparan di atas dapat disimpulkan bahwa kegiatan praktikum dalam pembelajaran IPA sangat penting dilakukan karena siswa sendiri dapat menemukan maupun membuktikan teori-teori IPA yang dipelajari melalui proses penyelidikan secara langsung baik di laboratorium maupun di lingkungan sekitar sehingga dapat mengembangkan ataupun meningkatkan keterampilan proses sains siswa. Kenyataan dilapangan keterampilan proses sains siswa masih rendah. Hal tersebut didukung oleh hasil penelitian Rahayu dkk (2017), di mana KPS siswa SD Sumedang memiliki nilai KPS masih rendah dengan rata-rata sebesar 9,8.

Melihat hal tersebut, guru-guru yang mengajar IPA di SD harus mampu mengemas dan menciptakan pembelajaran IPA sehingga dapat meningkatkan KPS siswa itu sendiri melalui kegiatan praktikum. Namun penelitian dari Sulistiyani dkk (2017) menunjukkan bahwa kemampuan guru masih kurang dalam tata cara pengelolaan laboratorium, perencanaan dan penilaian autentik serta kemampuan guru sangat kurang dalam pelaksanaan praktikum. Sesuai dengan hasil observasi di salah satu SD di Tampaksiring, KPS siswa masih rendah hal tersebut disebabkan karena guru jarang memberikan praktikum kepada siswa karena belum mempunyai buku panduan Khusus untuk praktikum. Guru selama ini menggunakan buku siswa sebagai pedoman untuk kegiatan praktikum. Namun dari hasil analisis buku siswa,tedapat permasalahan terkait petunjuk praktikum yang ada di buku siswa tersebut.

Salah satu permasalahannya adalah terdapat petunjuk praktikum tidak mencantumkan judul dan tujuan praktikum serta tidak terdapat landasan teori. Panduan/petunjuk praktikum tersebut dibuat sebagai pedoman dalam kegiatan praktikum sehingga siswa mudah dalam melakukan kegiatan praktikum. Dengan diberikan petunjuk praktikum dalam kegiatan praktikum siswa dapat mengembangkan dan meningkatkan Keterampilan proses sains (Prastowo, 2012). Asmaningrum dkk (2018) menyatakan bahwa panduan praktikum merupakan sebuah panduan yang memuat topik, tujuan, dasar teori, alat dan bahan, prosedur, lembar hasil pengamataan serta soal-soal evaluasi yang dibuat berdasar tujuan praktikum. Panduan praktikum tersebut juga dapat diartikan sebuah pedoman /petunjuk untuk memudahkan kegiatan praktikum yang memuat tujuan, landasan teori, alat dan bahan, langkah kerja, 
hasil pengamatan, simpulan serta soal-soal diskusi.

$\mathrm{Di}$ samping tidak memiliki panduan praktikum khusus, SD tersebut juga mengalami keterbatasan alat dan bahan praktikum yang mengakibatkan kegiatan praktikum jarang dilaksanakan. Menindaklanjuti permasalahan tersebut perlu dikembangkan panduan praktikum IPA sederhana SD berorientasikan lingkungan sekitar untuk dapat meningkatkan keterampilan proses sains siswa. Panduan praktikum yang dikembangkan, sebelum digunakan pada proses pembelajaran, tentunya harus dilakukan uji kelayakan dan kepraktsan terlebih dahulu.

Peneliti sudah melakukan uji kelayakan sebelumnya, di mana hasil dari uji kelayakannya adalah kualifikasi B dari para Ahli dan pendidik. Berarti dapat dinyatakan bahwa panduan praktikum yang telah dikembangkan layak untuk digunakan. Tahap selanjutnya peneliti mencari kepraktisan dari panduan praktikum yang sudah dikembangkan. Sesuai dengan hasil penelitian dari Novita (2020) menunjukkan bahwa tingkat kepraktisan buku pedoman praktikum yang dikembangkan adalah sangat praktis dengan skor 4,67 Berdasarkan hal tersebut, tujuan penelitian ini adalah melakukan uji kepraktisan dari panduan praktikum IPA sederhana SD berorientasikan lingkungan sekitar yang dikembangkan sehingga dapat mengetahui tingkat keterpakaian produk yang dikembangkan dalam hal ini panduan praktikum IPA sederhana SD berorientasikan lingkungan sekitar.

\section{METODE PENELITIAN}

Jenis penelitian ini merupakan penelitian deskriptif. Panduan praktikum menjadi subyek dalam penelitian ini dan kepraktisan dari panduan praktikum yang dirancang sebagai objek penelitian. Pengumpulan data kepraktisan dari panduan praktikum yang telah dirancang dengan menggunakan teknik nontes. Kepraktisan panduan praktikum yang dirancang perlu dilakukan untuk mengetahui tingkat keterpakaian produk yang dikembangkan dalam hal ini panduan praktikum IPA sederhana SD berorientasikan lingkungan sekitar.

\section{Teknik Pengumpulan Data}

Tingkat kepraktisan diukur dengan menggunakan angket yang diberikan kepada siswa untuk melihat tanggapan siswa setelah menggunakan panduan praktikum. Siswa yang diberikan angket berjumlah 35 orang. Aspek kepraktisan yang diniali berkaitan tampilan panduan praktikum, kejelasan kalimat dan tingkat keterbacaan, penggunaan panduan.

\section{Teknik Analisis Data}

Peneliti menggunakan skala likert untuk menganalisis angket validasi produk. Skala likert adalah skala yang memiliki gradulasi penilaian, yaitu sangat baik (5), baik (4), kurang baik (3), tidak baik (2) dan sangat tidak baik (1) (Koyan, 2011). Data kepraktisan yang telah diisi melalui angket dan kemudian dijumlahkan. Total skor yang sudah diperoleh dikonversikan menjadi data kualitatif dengan skala lima. Adapun konversi data kuantitatif ke data kualitatif menurut (Azwar, 2015) terdapat pada Tabel 1 berikut.

Tabel 1. Konversi Data Kuantitatif Ke Kualitatif Dengan Skala Lima

\begin{tabular}{cc}
\hline Interval & Kriteria \\
\hline$(M+1,50 s)<X$ & Sangat praktis \\
\hline$(M+0,50 s)<X$ & Praktis \\
$\leq(M+1,50 s)$ & \\
\hline$(M-0,50 s)<X$ & Cukup praktis \\
$\leq(M+0,50 s)$ & \\
\hline$(M-1,50 s)<X$ & Kurang praktis \\
$\leq(M-0,50 s)$ & \\
\hline$X \leq(M-1,50 s)$ & Tidak praktis \\
\hline
\end{tabular}

Keterangan:

$X=$ Total skor responden

$M=$ Mean ideal, $1 / 2$ (skor maksimal ideal+skor minimal ideal)

$\mathrm{S}=$ Simpangan baku ideal, 1/6 (skor maksimal ideal-skor minimal ideal)

\section{HASIL DAN PEMBAHASAN Hasil}

Analisis kepraktisan bertujuan untuk kepraktisan panduan praktikum yang dirancang perlu dilakukan untuk mengetahui tingkat keterpakaian produk yang dikembangkan dalam hal ini panduan praktikum IPA sederhana SD berorientasikan lingkungan Sekitar. Data kepraktisan panduan praktikum diperoleh dari hasil pengisian angket siswa. Hasil kepraktisan terhadap panduan praktikum juga dilengkapi dengan masukan serta komentar para dari sis w a. Hasil kepraktisan oleh siswa terhadap panduan praktikum IPA sederhana SD berorientasikan lingkungan sekitar terdapat pada Tabel 2.

Berdasarkan Tabel 2, menunjukkan bahwa skor kepraktisan panduan praktikum dari 35 orang siswa adalah sebagai berikut. Skor dengan kriteria sangat praktis berjumlah 3 orang dengan persentase $8 \%$, kriteria cukup praktis berjumlah 2 orang dengan persentase $6 \%$ dan kriteria praktis berjumlah 30 orang dengan persentase $86 \%$. Secara keseluruhan skor rata-rata kepraktisan panduan praktikum adalah 25 dengan kriteria praktis. 
Tabel 2. Konversi Kepraktisan Siswa Terhadap Buku Panduan Praktikum

\begin{tabular}{cccc}
\hline Interval & Kriteria & Jumlah & $\begin{array}{c}\text { Persentase } \\
(\%)\end{array}$ \\
\hline $27<\mathrm{X}$ & $\begin{array}{l}\text { Sangat } \\
\text { praktis }\end{array}$ & 3 & 8 \\
\hline $\begin{array}{c}23<\mathrm{X} \leq \\
27\end{array}$ & Praktis & 30 & 86 \\
\hline $\begin{array}{c}19<\mathrm{X} \leq \\
23\end{array}$ & $\begin{array}{l}\text { Cukup } \\
\text { praktis }\end{array}$ & 2 & 6 \\
\hline $\begin{array}{c}14<\mathrm{X} \leq \\
19\end{array}$ & $\begin{array}{l}\text { Kurang } \\
\text { praktis }\end{array}$ & - & - \\
\hline $\mathrm{X} \leq 14$ & $\begin{array}{l}\text { Tidak } \\
\text { praktis }\end{array}$ & - & - \\
\hline
\end{tabular}

\section{Pembahasan}

Sesuai dengan hasil dari penelitian, penilaian untuk kepraktisan panduan praktikum IPA sederhana SD berorientasikan lingkungan sekitar oleh siswa adalah sebgai berikut. Kriteria sangat praktis berjumlah 3 orang. Kriteria cukup praktis berjumlah 2 orang dan krieria praktis paling banyak, yaitu 30 orang. Dari keseluruhan rata-rata skor kepraktisan panduan praktikum adalah 25 dengan kriteria praktis. Dari hasil tersebut dapat dinyatakan bahwa panduan praktikum IPA sederhana SD berorientasikan lingkungan sekitar yang dikembangkan telah teruji kepraktisannya dengan mendapatkan kriteria praktis. Hal tersebut dimaksudkan bahwa panduan praktikum yang dikembangkan dapat dipakai oleh siswa. Meskipun hasil kepraktisan panduan pratikum belum berkriteria sangat praktis, panduan praktikum ini bisa tetap dipakai seiring dengan perbaikan pada panduan praktikum sesuai masukan - masukan dari siswa untuk kelengkapan panduan praktikum yang dikembangkan sehingga menjadi semakin sempurna.

Hasil penelitian yang diperoleh di dukung oleh hasil penelitian Chan \& Budiono (2019) menunjukkan tingakat kepraktisan dari buku petunjuk praktikum IPA SD adalah termasuk kategori praktis dengan rata-rata $78,75 \%$.

\section{SIMPULAN DAN SARAN \\ Simpulan}

Berdasarkan hasil penelitian dan pembahasan diuraikan simpulan sebagai berikut. Telah teruji kepraktisan dari panduan praktikum IPA sederhana SD berorientasikan lingkungan sekitar. Di mana skor dengan kriteria sangat praktis berjumlah 3 orang dengan persentase $8 \%$, kriteria cukup praktis berjumlah 2 orang dengan persentase $6 \%$ dan kriteria praktis berjumlah 30 orang dengan persentase $86 \%$. Keseluruhan skor rata-rata kepraktisan panduan praktikum adalah 25 dan memilki kriteria praktis.

\section{Saran}

Berdasarkan hasil penelitian yang telah dilakukan, penulis mengajukan saran sebagai berikut ; Hendaknya sebelum pemakaian suatu produk pengembangan dalam pembelajaran sebaiknya melakukan pengujian kevalidan dan kepraktisan dari produk tersebut sehingga dapat menghasilkan produk yang baik.

\section{DAFTAR RUJUKAN}

Asmaningrum, H. P., Koirudin, I., \& Kamariah, K. (2018). PENGEMBANGAN PANDUAN PRAKTIKUM KIMIA DASAR TERINTEGRASI ETNOKIMIA UNTUK MAHASISWA. Jurnal Tadris Kimiya. https://doi.org/10.15575/jtk.v3i2.3205

Azwar, S. (2015). Tes Prestasi, Fungsi dan Pengembangan Pengukuran Prestasi Belajar. In Pustaka Pelajar.

Chan, F., \& Budiono, H. (2019). Pengembangan Buku Petunjuk Praktikum IPA Berbasis Learning Cycle Bagi Siswa Kelas IV Sekolah Dasar. Jurnal Gentala Pendidikan Dasar. https://doi.org/10.22437/gentala.v4i2.7 919

Dahar, R. W. \& L. (1986). Interaksi Belajar Mengajar IPA. Erlangga.

Djamarah, S. B. (2006). Strategi Belajar Mengajar. PT. Rineka Cipta.

Faddilah, M. (2014). Implementasi Kurikulum 2013 Dalam Pembelajaran SD/MI, SMP/MTs, SMA/MA. Ar-Ruzz Media

Koyan, I. W. (2011). Assesmen Dalam Pendidikan. Universitas Pendidikan Ganesha Press.

Kunandar. (2007). Guru Profesional Implementasi Kurikulum Tingkat Satuan Pendidikan (KTSP) dan Sukses dalam Sertifikasi Guru. Raja Grafindo Persada.

Mulyasa. (2006). Menjadi Guru Profesional Menciptakan Pembelajaran Kreatif dan Menyenangkan. PT. Remaja Rosdakarya.

Novita, E. (2020). Pengembangan Buku Pedoman Praktikum Berbasis Keterampilan Proses Dasar Sains Kelas IV Sekolah Dasar. Journal Evaluation in Education (JEE).

Prastowo, A. (2012). Panduan Kreatif Membuat Bahan Ajar Inovatif. Diva Press.

Rahayu, A. H., Anggraeni, P. (2017). ANALISIS PROFIL KETERAMPILAN PROSES SAINS SISWA SEKOLAH DASAR DI KABUPATEN SUMEDANG. Pesona Dasar (Jurnal Pendidikan Dasar Dan Humaniora), 5(2), 22-33.

Rani, S. A., Wiyatmo, Y., \& Kustanto, H. (2017). 
Concept attainment worksheet to enhance concept knowledge and science process skills in physics instruction. Jurnal Pendidikan IPA Indonesia.

https://doi.org/10.15294/jpii.v6i2.10520

Ratnasari, D., Sukarmin, S., Suparmi, S., \& Harjunowibowo, D. (2018). Analysis of science process skills of summative test items in physics of grade $X$ in Surakarta. Jurnal Pendidikan IPA Indonesia.

https://doi.org/10.15294/jpii.v7i1.10439

Rustaman, Y. N. (2005). Strategi Belajar Mengajar Biologi. UN PRESS.

Sulistiyani, A., Rosidin, U., Maulina, M. (2015). Deskripsi Kemampuan Guru IPA Di SMP Negeri Bandar Lampung Dalam Mengelola Laboratorium. Junal Boiterdidik: Wahana Ekspresi IImiah, 3(4).

Sulistyorini, S. (2007). Pembelajaran IPA Sekolah Dasar. Tiara Wa-cana.

Susanto, A. (2013). Teori Belajar dan Pembelajaran di Sekolah Dasar. Kencana Prenada Media Group. 